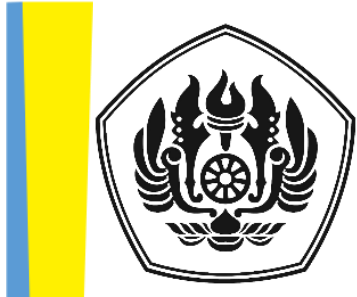

JURNAL POROS HUKUM PADJADJARAN

P-ISSN: 2715-7202 E-ISSN: 2715-9418

Artikel diterbitkan: 30 November 2020

DOI:

https://doi.org/10.23920/jphp .v2i1.333

Halaman Publikasi: http://jurnal.fh.unpad.ac.id/i ndex.php/JPHP/issue/archive

Diterbitkan oleh: Fakultas Hukum Universitas Padjadjaran

\section{PENGARUH ALIRAN HUKUM ALAM DALAM PENGELOLAAN SUMBER DAYA AIR DI INDONESIA}

\section{THE INFLUENCE OF NATURAL LAW THEORY ON THE WATER RESOURCES MANAGEMENT IN INDONESIA}

\author{
Nadia Astriani ${ }^{a}$ \\ ABSTRAK
}

Pengelolaan sumber daya air harus memperhatikan hubungan antara manusia dengan lingkungannya. Manusia dan lingkungan memiliki hubungan yang universal dan abadi, dimana satu sama lain akan saling mempengaruhi. Hukum yang universal dan abadi hanya ditemukan dalam Aliran Hukum Alam. Berdasarkan hal tersebut, artikel ini akan menitikberatkan pada perkembangan aliran hukum alam dan pengaruhnya dalam hukum lingkungan dan pengelolaan sumber daya air di Indonesia. Penelitian dilakukan dengan mengkaji teori-teori hukum alam dan melihat penerapan teori ini dalam sistem hukum Indonesia yang mengatur mengenai pengelolaan sumber daya air. Hasil penelitian menunjukkan bahwa prinsip Keadilan yang sangat menonjol dalam Hukum Lingkungan menunjukkan pengaruh dari aliran Hukum Alam, dan menjadi dasar bagi pengelolaan lingkungan di Indonesia. Prinsip keadilan, keberlanjutan dan efisiensi yang menjadi dasar pengelolaan sumber daya air dan posisi air yang secara kodrati adalah hak asasi manusia juga menguatkan pengaruh aliran hukum alam. Aliran Hukum Alam hanyalah satu dari aliran yang mempengaruhi pengelolaan lingkungan dan sumber daya alam. Sehingga perlu juga mempelajari pengaruh aliran dan teori hukum di luar aliran Hukum Alam untuk memperkaya pemahaman hukum lingkungan dan hukum sumber daya alam.

Kata kunci: sumber daya air; hukum alam; hukum lingkungan.

\begin{abstract}
Water resource management should heed of humans and environment relation. Human and environment had an eternal and universal relation, so they will always influence each other. The eternal and universal of law only can find Natural Law's theory. Based on that, this article will focus on development of natural law's theory and their impact on environmental law esspecially for water resources management in Indonesia. The research was conducted by examining natural law theories and seeing the application of this theory in the Indonesian legal system governing water resources management. The research showed that the principle of Justice which is very prominent in Environmental Law had big influence by Natural Law, and it becomes basis on environmental management in Indonesia. The principle of justice, sustainable and efficiency was the basis for management of water resources and considered of the water position was part
\end{abstract}

a Fakultas Hukum Universitas Padjadjaran, Jalan Raya Bandung Sumedang KM. 21 Jatinangor, email: nadia.astriani@unpad.ac.id 
of human rights, it conclude that natural law make big influence to environmental law it self. Bassically the Natural Law's theory was not the only one that affected environment and natural resources management. So, it is also necessary to study the influence of another legal philosophy and theories outside the natural law to enrich understanding of environmental law and natural resource law.

Keywords: environmental law; natural law; water resource management.

\section{PENDAHULUAN}

Air, pada hakikatnya adalah zat yang tidak dapat digantikan. Air adalah inti dari kehidupan manusia sebagaimana oksigen, selain itu air dalam kehidupan manusia juga memiliki nilai dan fungsi sosial, ekonomi dan religi. Sebuah kehidupan manusia yang bermartabat membutuhkan air. Oleh karena kedudukannya yang sangat penting bagi manusia, maka secara turun temurun air diperlakukan sebagai hak asasi, yaitu hak yang muncul dari kodrat manusia, kondisi historis, kebutuhan dasar, atau gagasan tentang keadilan. Hak atas air sebagai hak asasi tidak berasal dari negara, tetapi konteks ekologis tertentu dari ekologis manusialah yang memunculkan hak atas air itu. Sebagai hak asasi manusia, hak atas air merupakan hak guna, air boleh dimanfaatkan, tetapi tidak dimiliki¹. Artinya negara sekalipun tidak bisa memiliki air, melainkan menguasai sumber daya air untuk dimanfaatkan demi kepentingan rakyat.

Data FAO 2003 menunjukkan bahwa Indonesia merupakan negara terkaya kelima dalam hal jumlah air per penduduk per tahun dengan angka 13.381 m3/tahun/penduduk atau keempat di dunia dalam hal total aktual sumber daya air yang terbarukan di bawah Brazil, Canada dan Rusia. Data tahun 2011 menunjukkan terjadi penurunan ranking untuk Indonesia. Jumlah total sumber daya air yang terbarukan Indonesia pada tahun 2011 adalah 2.019 km3, di bawah Brazil, Rusia, Amerika Serikat, Canada, China dan Columbia². Data Kementrian PU pada tahun 2014 menyebutkan potensi ketersediaan air di Indonesia mencapai 3,9 triliun meter kubik, tetapi baru 12 milyar meter kubik atau 63m3/kapita yang dapat dikelola melalui reservoir ${ }^{3}$. Mengacu kepada perhitungan WHO (2010), kebutuhan air adalah 30 liter per individu per hari, yaitu 10 liter untuk minum dan 20 liter untuk sanitasi. Dengan asumsi jumlah penduduk Indonesia 252 juta orang, maka per hari jumlah air yang dikonsumsi

\footnotetext{
1 Vandana Shiva dalam Zaky Yamani, (2012), Kehausan di Ladang Air: Pencurian Air di Kota Bandung dan Hak Warga yang Terabaikan, LSPP dkk: Bandung, hlm. vi.

2 Kruha, (2016), Kajian Hak Atas Air, Indi Book Corner: Bandung, hlm. 31.

3 Ande Ahmad Sanusi, (2015), 'Pengembangan Infrastruktur wilayah', (Paparan dalam Diskusi Terbatas Pembangunan Infrastruktur di Jawa Barat), Bandung, 25 September 2015.
} 
oleh penduduk Indonesia adalah 7,56 milyar liter ${ }^{4}$. Melihat data-data tersebut, seharusnya jumlah air yang ada mencukupi kebutuhan penduduk air di Indonesia. Tetapi Data Kementrian PU tahun 2013 menunjukkan cakupan pelayanan nasional akses air bersih baru 67,7\% dan diharapkan terjadi peningkatan 2-3\% pertahun ${ }^{5}$. Data Unicef menunjukan $10-20 \%$ rakyat Indonesia menggunakan air minum yang berasal dari sumber air yang tidak layak.

Secara umum ketersediaan air di Indonesia masih cukup untuk memenuhi kebutuhan hidup seluruh rakyat Indonesia. Tetapi distribusi yang tidak merata, menyebabkan pada kurun waktu tertentu (biasanya di musim kemarau), sebagian masyarakat kesulitan mengakses air bersih. Distribusi air yang tidak merata disebabkan oleh dua hal, yaitu: karakteristik alam Indonesia sendiri dan perilaku manusia. Data dari Dewan Sumber Daya Air Nasional tahun 2014 menunjukkan bahwa pulau Jawa, Bali dan NTT pada bulan kemarau mengalami defisit air, sementara pada musim hujan pasokan air melampaui kebutuhan. Ketidakseimbangan air di musim hujan dan musim kemarau ini diperparah oleh perilaku manusia terhadap lingkungannya. Aktivitas pembangunan yang dilakukan manusia berupa alih fungsi lahan untuk kebutuhan perkebunan/pertanian dan pertambangan di wilayah hulu, serta pembangunan kota dan industri di bagian hilir mempengaruhi daur hidrologi air. Hal ini menyebabkan kekeringan akibat kekurangan air di musim kemarau, dan menyebabkan banjir di musim hujan.

Pengelolaan sumber daya air harus memperhatikan hubungan antara manusia dengan lingkungannya. Manusia dan lingkungan memiliki hubungan yang universal dan abadi, dimana satu sama lain akan saling mempengaruhi. Hukum yang universal dan abadi hanya ditemukan dalam Aliran Hukum Alam.

Atas dasar pemikiran tersebut, artikel ini akan berfokus pada dua identifikasi masalah, yaitu:

1. Bagaimana perkembangan aliran hukum alam dan pengaruhnya dalam hukum lingkungan di Indonesia?

2. Bagaimana pengaruh aliran hukum alam dalam pengelolaan sumber daya air di Indonesia?

\footnotetext{
${ }^{4}$ Rizky $\mathrm{R}$ Sigit, Air Perlu Dilestarikan. Inilah lima fakta air dan kondisinya di Indonesia, http:/ / www.mongabay.co.id/2015/03/23/air-perlu-dilestarikan-inilah-lima-fakta-air-dan-kondisinya-di-indonesia/ diunduh 25 Mei 2017 Pkl. 14.00.

${ }^{5}$ Loc. Cit.
} 


\section{Perkembangan Aliran Hukum Alam dan pengaruhnya pada Hukum Lingkungan di Indonesia}

Sudjito mengatakan filsafat ilmu hukum adalah institusi pencarian jawaban atas persoalan-persoalan yang dihadapi manusia, mulai dari persoalan ketuhanan, alam semesta, sampai kepada persoalan manusia itu sendiri. Satjipto Rahardjo mengemukakan pendapatnya bahwa filsafat hukum itu mempersoalkan pertanyaanpertanyaan yang bersifat dasar dari hukum. Gustav Radbruch merumuskannya dengan sederhana yaitu bahwa filsafat hukum itu adalah cabang filsafat yang mempelajari hukum yang benar, sedangkan Langemeyer mengatakannya pembahasan secara filosofis tentang hukum ${ }^{6}$. Pertanyaan dan pemikiran filosofis tentang hukum ini membuat para ilmuwan kemudian melakukan penelitian yang hasilnya berkembang menjadi berbagai teori hukum. Teori hukum menurut JJ.H. Bruggink adalah suatu keseluruhan pernyataan yang saling berkaitan berkenaan dengan sistem konseptual aturan-aturan hukum dan putusan-putusan hukum dan sistem tersebut untuk sebagian yang pentig di positifkan. Definisi ini bermakna ganda dimana teori dipandang sebagai suatu proses satau aktivitas dan sebagai produk atau hasil aktivitas itu?

Berbagai klasifikasi teori hukum kemudian dibuat oleh para penulis hukum, antara lain, Northrop yang membagi menjadi positivisme hukum, pragmatic legal realisme, neo kantian dan kelsenian, ethical jurisprudence, functional antropological dan sociological jurisprudence, dan hukum alam. Friedman membagi Aliran hukum tersebut sebagai aliran hukum alam, aliran yang didasarkan pada pengaruh perkembangan masyarakat terhadap hukum, aliran positivisme dan positivisme hukum dan aliran yang didasarkan atas kegunaan dan kepentingan. Soerjono Soekanto menyebutkan: mazhab formalitas, mazhab sejarah dan kebudayaan, aliran utilitarianisme, aliran sociological jurisprudence dan aliran realisme hukum. Satjipto Rahardjo mengetengahkan teori-teori Yunani dan Romawi, hukum alam, positivisme dan utilitarianisme, teori hukum murni, pendekatanpendekatan sosiologis. Sedangkan Lili Rasjidi membagi menjadi aliran hukum alam,

\footnotetext{
6 Inge Dwisvimiar, 'Keadilan dalam Perspektif Filsafat Ilmu Hukum' (2011), Jurnal Dinamika Hukum, Universitas Jenderal Soedirman, hlm. 4.

7 JJ. H. Bruggink alih bahasa B. Arief Shidarta, (2015), Refleksi tentang Hukum: Pengertian- Pengertian Dasar dalam Teori Hukum, Cetakan ke IV, Citra Aditya Bakti, Bandung, hlm. 160.
} 
aliran hukum positif, mazhab sejarah, sociological jurisprudence dan pragmatic legal realism ${ }^{8}$.

Hukum alam pada prinsipnya bersumber dari Tuhan (irrasional) dan bersumber dari rasio manusia9. Aliran filsafat hukum alam secara eksplisit mengatakan bahwa manusia/masyarakat tidak dapat membuat hukum, karena karakter universalistik dari hukum hanya mungkin bersumber dari eksternal masyarakat tersebut - divine law ${ }^{10}$. Yang dimaksudkan dengan hukum alam menurut ajaran ini ialah hukum yang berlaku universal dan abadi. Menilik sumbernya hukum alam ini ada yang bersumber dari Tuhan (irasional dan yang bersumber dari akal (rasio) manusia). Pemikiran hukum alam yang berasal dari Tuhan dikembangkan misalnya dan terutama oleh para pemikir skolastik pada Abad Pertengahan, seperti Thomas Aquino, Gratianus, John Salisbury, Dante, Piere Dubois, Marsilius Padua, Johannes Haus dan lain-lain. Sedangkan para pendasar dari ajaran hukum alam yang bersumber dari akal manusia ialah, misalnya, Hugo de Groot, Christian Thomasius, Immanuel Kant, Fichte, Hegel dan Rudolf Stammler. Menurut Friedmann, sejarah tentang hukum alam merupakan sejarah umat manusia dalam usahanya untuk menemukan apa yang dinamakan keadilan yang mutlak (absolute justice) selain kegagalan-kegagalan yang dialaminya11.

Ajaran hukum alam dengan landasan ketuhanan mencapai puncak perkembangannya melalui teori-teori kaum skolastik pada Abad Pertengahan. Amat terkenal, misalnya, pemikiran-pemikiran hukum alam dari Thomas Aquino. Thomas Aquino membagi konsep hukum alamnya atas dua jenis sebagai berikut:

a. Principia prima, yaitu asas-asas yang dimiliki oleh manusia sejak lahir dan tidak dapat diasingkan daripadanya. Oleh karena itu, principia prima tidak dapat berubah menurut tempat dan waktu.

b. Principia secundaria, yaitu asas yang bersumber dari principia prima, sebaliknya tidak bersifat mutlak dan dapat berubah pada setiap waktu dan tempat. Seringkali asas ini dikatakan sebagai penafsiran manusia dengan menggunakan rasionya terhadap principia prima. Penafsiran ini bervariasi, dapat baik atau buruk. Suatu penafsiran

\footnotetext{
8 Lili Rasjidi dan Ira Thania Rasjidi, (2016), Pengantar Filsafat Hukum, Penerbit Mandar Maju, Bandung, hlm. 53.

9 Lili Rasjidi dan Ira Thania Rasjidi, (2007), Dasar Dasar Filsafat dan Teori Hukum, Cetakan ke-10, Citra Aditya Bakti, Bandung, hlm. 48. Hukum alam yang rasional bersumber dari ratio Tuhan dianut oleh kaum Scholastik seperti pemikiran Thomas van Aquino dalam bukunya Summa Theologica dengan Lex Aeterna, dimana ratio Tuhan mengatur segala hak dan merupakan sumber dari segala hukum.

${ }^{10}$ Suadamara Ananda, (2006), 'Hukum dan Moralitas', Jurnal Hukum Pro Justitia, Volume 24 No 3.

${ }^{11}$ Loc. Cit.
} 
dapat mengikat umum jika hukum positif memberikan pada asas-asas ini kekuasaan mengikat, misalnya dalam bentuk undang-undang.

Gratianus mengatakan bahwa manusia itu dikuasai oleh dua macam hukum, yaitu hukum alam dan adat kebiasaan. Hukum alam mulai ada di dunia bersama-sama dengan adanya manusia sebagai yang berakal. Hukum ini bersifat abadi dan universal. Dalam hubungan dengan hukum positif dan hukum lainnya, kedudukan hukum alam lebih tinggi. William Occam mengemukakan adanya hierarki pada hukum sebagai berikut ${ }^{12}$ :

a. Hukum universal, yaitu yang mengatur tingkah laku manusia yang bersumber dari rasio alam

b. Hukum lainnya yang juga bersumber dari rasio alam yang bersifat mengikat masyarakat

c. Hukum yang bersumber dari alam, tetapi yang dapat diubah oleh penguasa

Kemenangan kaum borjuis liberal pada abad ke-19 adalah awal dari reaksi terangterangan terhadap metafisika dan teori hukum alam. Bersamaan dengan perkembangan ilmu alam empiris dan pecahnya ideologi agama, ilmu hukum borjuis berubah dari hukum alam menjadi positivisme hukum. Hukum tidak lagi dianggap sebagai kategori abadi dan mutlak, muatannya dianggap mengalami perubahan historis dan hukum itu sendiri, sebagai hukum positif diakui sebagai fenomena yang dikondisikan berdasarkan faktor-faktor spasial dan temporal. Namun, konsep nilai hukum mutlak tidak sepenuhnya hilang. Konsep tersebut tetap menjadi ide yang diakui bahkan dalam yurisprudensi positivis, yaitu ide keadilan etis. Ketika perbedaan antara hukum dan keadilan digambarkan dengan tegas, keduanya terikat bersama-sama dengan ikatan yg relatif tampak. Untuk menjadi hukum, sehingga teori menerimanya, sistem negara positif harus memberikan beberapa perhatian kepada keadilan, memastikan keadilan menjadi minimum etis, mengusahakan, meskipun tidak memadai, menjadi hukum yang benar, yaitu hukum yang adil. Untuk menjadi hukum, hukum positif harus menyesuaikan beberapa ukurannya dengan konsep keadilan. ${ }^{13}$

Positivisme hukum sendiri ternyata kemudian tidak mampu untuk mengikuti rasa keadilan yang tumbuh di dalam masyarakat karena hukum yang sifatnya tertulis tidak dapat diubah-ubah setiap saat. Rasa keadilan yang tercermin pada suatu kitab undang-

$12 \mathrm{Ibid}, \mathrm{hlm}$. 105-107.

${ }^{13}$ Hans Kelsen, (2012), Pengantar Teori Hukum, Cetakan ke-IV, Penerbit Nusa Media, Bandung, hlm. 53-54. 
undang, misalnya, mungkin hanya selaras dengan rasa keadilan dalam masyarakat pada waktu dikitabkannya undang-undang itu. Masyarakat yang terus berubah membawa serta perubahan pada keadilan yang hidup di dalam masyarakat itu. Karena dirasakan ketentuan yang ada tidak atau kurang lagi mencerminkan rasa keadilan yang dikehendaki, maka orang berusaha mencari keadilan lain, dan ini berarti orang berpegang kembali kepada ajaran hukum alam ${ }^{14}$. Hart, yang seorang positivis sekalipun, mengakui dalam bukunya bahwa ada doktrin-doktrin hukum alam yang tak terbantahkan, terkait dengan hukum dan moral. Beberapa kebenaran dasar yang harus dipahami ketika membahas hukum dan moral adalah sebagai berikut ${ }^{15}$ :

1. Human vulnerability (Kerentanan Manusia), Manusia rentan terhadap serangan fisik, oleh karena itu dalam kehidupan sosial yang paling penting adalah membatasi penggunaan kekerasan yang menimbulkan kerugian fisik apalagi sampai membunuh.

2. Approximate equality of people (Kesetaraan yang hampir sama), fakta bahwa tidak ada individu yang sedemikian kuatnya melebihi yang lainnya sehingga ia mampu, tanpa bekerjasama, mendominasi atau menundukkan manusia lain untuk waktu lama, menyebabkan perlunya suatu sistem kompromi dan timbal balik yang menjadi dasar kewajiban hukum dan moral

3. Limited altruism (Altruisme terbatas), altruisme manusia memiliki keterbatasan cakupan dan masa yang tidak tentu dan kecendrungan untuk agresi cukup sering berlangsung, sehingga akan menjadi fatal bagi kehidupan jika tidak dikontrol.

4. Limited resources (Sumber Daya Terbatas), kebutuhan manusia terhadap sumber daya meningkat seiring pertambahan populasi, sementara jumlah sumber daya tetap. Hal ini menyebabkan timbulnya kepemilikan yang perlu diatur dan juga menimbulkan peraturan yang memungkinkan manusia mengalihkan, menukar dan menjual produk-produk mereka.

5. Limited understanding and strength of will (Keterbatasan Pemahaman dan Kemauan), Manusia memiliki keterbatasan pemahaman dan kemauan. Kebanyakan manusia mampu memahami dan mampu mengorbankan kepentingan jangka pendek yang dituntut oleh kepatuhan, meskipun demikian ada kalanya orang tergoda untuk lebih memilih kepentingan mereka meski melanggar peraturan yang ada, oleh karena itu

\footnotetext{
${ }^{14}$ Lili Rasjidi dan Ira Thania Rasjidi, Ibid, hlm. 55.

${ }^{15}$ H.L.A. Hart, (2010), Konsep Hukum, Penerbit Nusa Media, Bandung, hlm. 300-306.
} 
sanksi-sanksi diperlukan sebagai jaminan bagi mereka yang patuh secara sukarela tidak akan menjadi korban bagi mereka yang tidak patuh.

Karena hal-hal diatas, ada kebutuhan alami untuk melindungi individu, barang dan perjanjian dalam derajat-derajat tertentu. Kebutuhan ini mempengaruhi isi dari hukum. Hart mengatakan hukum yang berlawanan dari 5 kebenaran dasar ini adalah hukum yang gagal. Meskipun demikian karena Hart berkeras memisahkan hukum dan moral, menyatakan bahwa, meskipun hal-hal tersebut perlu diterapkan dalam hukum, tetapi jika diterapkan sepenuhnya akan tidak adil dan sulit untuk dipatuhi atau diaplikasikan. ${ }^{16}$

Teori keadilan moral yang dikemukakan Plato menyatakan keadilan sebagai kebajikan tertinggi dari suatu Negara yang baik. Keadilan timbul karena pengaturan atau penyesuaikan yang memberikan tempat yang selaras kepada bagian-bagian yang membentuk suatu masyarakat. Lebih lanjut Plato menyatakan keadilan dan hukum merupakan suatu substansi rohani umum dari suatu masyarakat yang membuat dan menjalankan pekerjaan yang menurut sifat dasarnya paling cocok baginya. Konsep keadilan ini disebabkan pada prinsip keselarasan. ${ }^{17}$

Pengertian keadilan meliputi beberapa aspek. Secara umum dikatakan, bahwa keadilan berarti dengan sukarela secara tetap dan mantap terus menerus memberikan kepada tiap orang apa yang memang sudah menjadi bagiannya atau haknya (Iustitia est constans et perpetua voluntas ius suum cuique tribuere). Berdasarkan rumusan tadi, pengertian keadilan dapat dibedakan dalam beberapa aspek berikut ini. Keadilan Distributif (iustitia distributiva) adalah keadilan yang berupa kewajiban pimpinan masyarakat untuk memberikan kepada para warga masyarakat beban sosial, fungsifungsi, balas jasa dan kehormatan secara proporsional (seimbang) dengan kecakapan dan jasa masing-masing. Keadilan Komutatif (iustitia commutativa) adalah kadilan yang berupa kesenilaian antara prestasi dan kontra-prestasi, antara jasa dan balas jasa dalam hubungan-hubungan antar-warga, atau, dilihat dari sudut pemerintah memberikan kepada setiap warga secara sama tanpa menghiraukan perbedaan-perbedaan keadaan pribadi ataupun jasanya. Keadilan Vindikatif (iustitia vindicativa) adalah keadilan yang berupa memberikan ganjaran (hukuman) sesuai dengan kesalahan yang bersangkutan.

\footnotetext{
${ }^{16}$ Hari Chand, 2005, Modern Jurisprudence, Internasional Law book Services, Malaysia, hlm. 54.

${ }^{17}$ Maret Priyanta, 'Pengelolaan Hutan Berkelanjutan dalam Kerangka Pembaruan Sistem Hukum Lingkungan dan Penataan Ruang berbasis Perubahan Iklim' (Disertasi yang tidak dipublikasikan, Program Pendidikan Doktor Ilmu Hukum, Fakultas Hukum Universitas Padjadjaran, 2017), hlm. 38.
} 
Keadilan Protektif (iustitia protectiva) adalah keadilan berupa perlindungan yang diberikan kepada setiap manusia, sehingga tak seorangpun akan mendapat perlakuan sewenang-wenang. Rumusan-rumusan tentang keadilan tadi adalah rumusan yang abstrak. Isi dari rumusan-rumusan tadi akan ditentukan oleh kondisi yang di dalamnya keadilan hendak diwujudkan. Yang pasti adalah, bahwa keadilan menuntut bahwa setiap orang tanpa kecuali berkewajiban untuk bertindak sesuai dengan apa yang diwajibkan kepadanya oleh hukum. ${ }^{18}$

Dalam kaitannya dengan konsep keadilan, John Rawls dan Amartya Sein mengatakan untuk memahami bagaimana keadilan dapat dicapai, penting untuk mempelajari kehidupan manusia dan perjalanan hidup serta realisasinya. Untuk itu terdapat 3 prinsip keadilan, yaitu keadilan berdasarkan hak, keadilan berdasarkan kemampuan/ jasa dan keadilan berdasarkan kebutuhan. ${ }^{19}$ Keadilan lingkungan dapat dikategorikan keadilan berdasarkan hak, yaitu hak untuk mendapatkan lingkungan yang sehat dan layak serta hak bagi generasi masa kini dan generasi mendatang. Dalam kaitannya dengan prinsip keadilan distributif yang dikemukakan oleh Aristoteles, bahwa keadilan adalah kelayakan dalam tindakan manusia dan titik tengah diantara dua ujung namun intinya bahwa distribusi tersebut tewujud dalam suatu perimbangan (proposional). ${ }^{20}$

Prinsip keadilan antargenerasi (intergenerational equity) dirumuskan dalam prinsip ketiga Deklarasi Rio yang menyatakan bahwa "The right to development must be fulfilled so as to equitably meet developmental and environmental." Prinsip keadilan antargenerasi mengandung makna bahwa pemanfaatan sumber daya alam oleh generasi sekarang tidak boleh mengorbankan kepentingan atau kebutuhan generasi mendatang. Prinsip ini juga mengandung makna, bahwa generasi sekarang memiliki kewajiban untuk menggunakan sumber daya alam secara hemat dan bijaksana serta melaksanakan konservasi sumber daya alam, sehingga sumber daya alam tersedia dalam kualitas dan kuantitas yang cukup untuk dimanfaatkan oleh generasi mendatang. ${ }^{21}$

Teori Keadilan Pancasila menurut Notonegoro, ditunjukkan oleh sila kelima keadilan sosial bagi seluruh rakyat Indonesia yang dimaknai bahwa keadilan yang

\footnotetext{
${ }^{18}$ B. Arief Sidharta, (2012), 'Filsafat Hukum dalam Konteks Ideologi Negara Pancasila (Makalah)', Konferensi ke-2 Asosiasi Filsafat Hukum Indonesia, Semarang, 16-17 Juli 2012, hlm. 33.

${ }^{19}$ Ida Nurlinda, (2014), Membangun Pluralisme Hukum dalam Kerangka Unifukasi Hukum Agraria, Pusat Studi Hukum Lingkungan dan Penataan Ruang Fakultas Hukum UNPAD dan Logoz Publishing, Bandung, hlm. 78.

${ }^{20}$ Maret Priyanta, Loc. Cit.

${ }^{21}$ Takdir Rahmadi, (2011), Hukum Lingkungan di Indonesia, Rajagrafindo, hlm.15.
} 
dimaksud adalah keadilan yang berketuhanan Yang Maha Esa, berkemanusiaan yang adil dan beradab, yang berkerakyatan yang dipimpin oleh hikmat kebijaksanaan dalam permusyawaratan/ perwakilan. ${ }^{22}$ Pancasila sebagai dasar filsafat Negara Indonesia, meletakkan sila keadilan sosial bagi seluruh rakyat Indonesia tersebut sebagai tujuan Negara. Soepomo menyatakan"...kita mendirikan Negara Indonesia yang makmur, bersatu, berdaulat, adil. Maka Negara akan bisa adil jikalau Negara itu menyelenggarakan keadilan rakyat kepada cita-cita yang luhur, menurut aliran zaman". ${ }^{23}$

Dalam kaitannya dengan perkembangan zaman dan perkembangan aliran hukum alam baru (neo naturalisme), keadilan Pancasila pada awal perkembangannya hanya bertujuan untuk kesejateraan manusia, namun dalam perkembangan aliran hukum alam telah mengubah cara pandang dan cara pendekatan bahwa pandangan antroposentris dimana hanya manusia sebagai intinya memasuki pandangan baru dimana hukum berorientasi dan bertujuan untuk kelestarian fungsi lingkungan (ekosentris) dan manusia sebagai salah satu makhluk Tuhan yang diberi kelebihan akal budi disamping sebagai sumber daya lingkungan. ${ }^{24}$

Masuknya Aliran hukum alam (Baru) ke Indonesia yang menempatkan bangsa Indonesia berkedudukan sama dengan unsur-unsur lingkungan lainnya dalam suatu ekosistem, sekaligus bertanggung jawab atas pelestariannya, menjadi landasan bagi pembentukan hukum yang mengatur segi-segi lingkungan hidup. ${ }^{25}$ Daud Silalahi berpandangan bahwa masuknya aspek lingkungan pada proses pembentukan hukum menjadi sebuah keharusan bagi konsepsi pembangunan yang berwawasan lingkungan (ecodevelopment) dan sesuai dengan prinsip-prinsip yang disepakati dalam berbagai konferensi internasional. ${ }^{26}$

Salah satu perkembangan wacana pentingnya perlindungan lingkungan adalah diletakannya dasar-dasar konseptual mengenai lingkungan dan pembangunan berkelanjutan yang setara dengan konsep demokrasi, nomokrasi dan bahkan teokrasi. Keempat gagasan kekuasaan tersebut yaitu demokrasi, nomokrasi, teokrasi dan

\footnotetext{
22 Maret Priyanta, Loc. Cit.

${ }_{23}^{2} \mathrm{Id}$.

24 Amiruddin A. Dajaan Imami, (2014), Hukum Penataan Ruang Kawasan Pesisir: Harmonisasi dalam Pembangunan Berkelanjutan, Logoz Publishing, hlm. 17-19, lihat juga Otto Soemarwoto, (2004), Atur Diri Sendiri: Paradigma Baru Pengelolaan Lingkungan Hidup, Gadjah Mada University Press, Cetakan ketiga, hlm. 85-86.

${ }^{25}$ Amiruddin A. Dajaan Imami, Ibid, hlm. 16.

${ }^{26}$ M Daud Silalahi, (2001), Hukum Lingkungan Dalam Sistem Penegakan Hukum Lingkungan Indonesia, Alumni, hlm. 32.
} 
ekokrasi serta ditambah lagi dengan monarki, juga dapat ditemukan unsur-unsurnya dalam kandungan nilai dan Norma dalam Konstitusi 1945.27

\section{Pengaruh Aliran Hukum Alam dalam Pengelolaan Sumber Daya Air di Indonesia}

Sumber daya air terdiri atas air, sumber air dan daya air yang terkandung di dalamnya. Sementara yang termasuk air adalah semua air yang terdapat di atas atau di bawah permukaan tanah, termasuk air permukaan, air tanah, air hujan dan air laut yang berada di darat ${ }^{28}$. Pengertian ini menunjukkan luasnya ruang lingkup baik air maupun sumber daya air, yang harus dikelola oleh negara. Posisi Air sebagai inti dari kehidupan manusia, menjadikan air sebagai hak asasi manusia. Majelis Umum Perserikatan Bangsa-Bangsa (PBB) telah mendeklarasikan akses terhadap air dan sanitasi sebagai hak asasi manusia dalam Sidang Umum PBB yang berlangsung pada akhir bulan Juli 2010. Sebelumnya, hak atas air telah diakui dalam berbagai konvensi international. Misalnya pasal 14, paragraf 2 Konvensi tentang Penghapusan Segala Bentuk Diskriminasi terhadap Perempuan 1984 menyatakan bahkan Negara penandatangan harus menjamin kepada perempuan Hak untuk "menikmati kondisi hidup yang layak, terutama dalam kaitan dengan suplai air". Pasal 24 paragraf 2 Konvensi Hak Anak-anak 1989 mewajibkan negara penandatangan untuk memerangi penyakit dan kekurangan gizi "melalui pengaturan tentang makanan bergizi dan air minum yang layak".

Pada 28 Oktober 2005, pemerintah Indonesia mengesahkan Konvenan Internasional Hak Ekonomi, Sosial dan Budaya (ICESCR) menjadi UU No.11/2005 dan Konvenan Internasional Hak Sipil dan Hak Politik (ICCPR) menjadi UU No.12/2005. Ratifikasi tersebut menimbulkan konsekuensi terhadap terhadap pelaksanaan hak-hak manusia. Negara sebagai pemangku kewajiban HAM harus menjalankan kewajiban HAM dalam bentuk penghormatan (to respect), melindungi (to protect) dan memenuhi (to fulfill). Negara harus memenuhi hak-hak warga Negara, karena itulah Negara mendapatkan Hak menguasai sumberdaya strategis sebagai suatu amanat publik (public trust) dan menjamin bahwa setiap orang tanpa diskriminasi apapun, memiliki hak untuk mendapatkan air yang cukup (sufficient), sehat (save), dapat diakses (physically accessible) dan terjangkau (affordable).

\footnotetext{
${ }_{27}$ Jimly Asshiddiqie, (2010), Green Constitution, Nuansa Hijau Undang-Undang Dasar Negara Republik Indonesia Tahun 1945, Rajawali Pres, hlm. 8.

${ }^{28}$ Pasal 1 angka (1) dan (2) UU No. 7 tahun 2004 tentang Sumber Daya Air.
} 
Kebijakan nasional pengelolaan sumber daya air dilakukan melalui lima misi sebagai berikut 29 :

1. Meningkatkan konservasi sumber daya air secara terus menerus;

2. Mendayagunakan sumber daya air untuk keadilan dan kesejahteraan masyarakat;

3. Mengendalikan dan mengurangi daya rusak air;

4. Meningkatkan peran masyarakat dan dunia usaha dalam pengelolaan sumber daya air; dan

5. Membangun jaringan sistem informasi sumber daya air nasional yang terpadu antarsektor dan antarwilayah.

Konservasi sumber daya air adalah upaya memelihara keberadaan serta keberlanjutan keadaan, sifat, dan fungsi sumber daya air agar senantiasa tersedia dalam kuantitas dan kualitas yang memadai untuk memenuhi kebutuhan makhluk hidup, baik pada waktu sekarang maupun yang akan datang.

Pendekatan yang digunakan dalam pengelolaan sumber daya air adalah pendekatan Pengelolaan Sumber Daya Air Terpadu. Mengacu pada The Global Water Partnership, Pengelolaan Sumber Daya Air Terpadu/ Integrated Water Resources Management selanjutnya disebut IWRM adalah "proses yang mendorong terciptanya pengembangan dan pengelolaan sumber daya air, lahan, dan sumber daya lainnya yang terkait secara terkoordinasi sehingga upaya optimalisasi keuntungan ekonomi dan kesejahteraan sosial dapat dicapai secara berkeadilan tanpa mengorbankan keberlanjutan ekosistem". Secara singkat, pengelolaan sumber daya air terpadu adalah konsep pengelolaan sumber daya air yang dilakukan secara efisien, berkeadilan, dan berkelanjutan. Keberlanjutan pengelolaan sumber daya air tersebut ditentukan tidak hanya dari sisi pengelolaan pasokan air (water supply) yang menekankan pada pembangunan infrastruktur fisik, melainkan juga dari aspek pengelolaan kebutuhan air (water demand) yang menekankan pada pendekatan regulasi ${ }^{30}$.

Konferensi Dublin tentang Air dan Pertemuan Tingkat Tinggi Rio de Janeiro tentang Pembangunan Berkelanjutan yang diselenggarakan pada tahun 1992, menjelaskan kerangka kerja IWRM dirancang untuk perbaikan pengelolaan sumber daya air yang didasarkan pada empat prinsip sebagai berikut ${ }^{31}$ :

\footnotetext{
${ }^{29}$ Lampiran Peraturan Presiden Republik Indonesia Nomor 33 Tahun 2011 Tentang Kebijakan Nasional Pengelolaan Sumber Daya Air.

${ }^{30}$ Chay Asdak, 2015, Laporan Akhir Kebijakan Nasional Konservasi Sumber Daya Air Terpadu, hlm. 6.

31 Id.
} 
1. Sumber daya air bersifat terbatas, rentan dan sebagai penopang kehidupan (manusia dan alam);

2. Pengelolaan dan pengembangan sumber daya air harus didasarkan pada pendekatan partisipatif yang melibatkan pengguna air, perencana, dan pengambil keputusan pada semua tingkatan;

3. Perempuan memainkan peran penting dalam penyediaan, pengelolaan, dan penyelamatan/konservasi sumber daya air; dan

4. Air memiliki nilai ekonomi dan seharusnya dipandang sebagai sumber daya ekonomi.

Konsep IWRM menekankan pentingnya keseimbangan antara kebutuhan dan pasokan sumber daya air. Khusus untuk kebutuhan sumber daya air, adalah keseimbangan antara kebutuhan air untuk kehidupan manusia (umumnya dalam bentuk blue water) dan kebutuhan air untuk ekosistem (green water). Untuk pasokan sumber daya air, dicapai melalui upaya-upaya pengembangan sumber daya air, utamanya melalui peningkatan cadangan sumber daya air dan penurunan pemanfaatan sumber daya air (efisiensi pemanfaatan air). Peningkatan cadangan sumber daya air dilakukan dengan cara konservasi dan perlindungan sumber daya air. Sedangkan penurunan pemanfaatan sumber daya air dilakukan dengan cara perubahan perilaku konsumsi sumber daya air yang lebih efisien dan melakukan terobosan inovasi teknologi pemanfaatan sumber daya air, misalnya sistem irigasi atau industri hemat air. ${ }^{32}$

Air bagi masyarakat muslim, memiliki sisi spiritualitas karena air digunakan untuk mensucikan diri. Kedudukan dan pentingnya air dalam kehidupan beragama dan bernegara dijelaskan dalam Al-Qur'an dan Hadits. Al-Qur'an mengatakan, “...Dan Kami jadikan dari air itu segala sesuatu yang hidup...." (QS. Al Anbiya' [21]:30). Berkaitan dengan pengeloaan air, 2 hal yang menjadi poin penting adalah ${ }^{33}$ :

1. Pasokan air adalah tetap, dan oleh karena itu, harus dikelola karena pasokan tidak dapat ditingkatkan:"Dan kami turunkan air dari langit menurut suatu ukuran dan kami jadikan air itu menetap di bumi" (QS. Al Mu'minuun [23]:18).

\footnotetext{
32 Ibid, hlm. 7.

${ }^{33}$ Hayu S. Prabowo, Konservasi Air Dalam Perspektif Islam, http://mui-lplhsda.org/konservasi-air-dalam-perspektifislam/, 3 Maret 2015, diakses pada 11 Mei 2017.
} 
2. Air tidak boleh disia-siakan karena diperlukan oleh seluruh makhluk. "Sesungguhnya pemboros-pemboros itu adalah Saudara-saudara syaitan" (QS. Al Israa' [17]:27).

Lebih lanjut mengenai pengelolaan air, dinyatakan dalam haditshadits, diriwayatkan oleh Ahmad dan Abû Dâwud bahwa "Manusia berserikat dalam tiga hal: dalam padang rumput, air, dan api". Yang dimaksud hak milik umum ialah sesuatu yang digunakan bagi keperluan umum. Mata air dan sumur wajib dimanfaatkan bagi orang umum. Seseorang yang mempunyai sumber air wajib mengizinkan orang lain mengambil airnya, tidak dibenarkan memonopoli untuk diri dan keluarganya saja. Islam juga melarang membuang kotoran ditempat-tempat yang mengakibatkan tercemarnya air sehingga tidak dapat dimanfaatkan kembali. “sesungguhnya Rasulullah SAW melarang kencing di air yang tidak mengalir." (HR. Muslim). Mengenai jumlah pasokan air yang tetap, Rasulullah SAW bersabda bahwa "membasuh, atau mandi dengan satu sha' hingga lima mud, dan berwudlu dengan satu mud." (HR. Bukhari). Satu mud setara dengan 2/3 liter dan satu sha adalah 4 Mud. Hadits ini menunjukkan pendekatan logis untuk penggunaan air yang berkelanjutan di tandus Arab tempat Rasulullah SAW tinggal. Terakhir, Rasulullah SAW menekankan bahwa air tidak boleh disia-siakan. Rasulullah SAW melarang pemborosan air, meskipun dalam keadaan air melimpah. Rasulullah SAW Saw melihat Sa'ad yang sedang berwudhu, lalu beliau berkata, "Pemborosan apa itu, hai Sa'ad?" Sa'ad bertanya, "Apakah dalam wudhu ada pemborosan?" Rasulullah SAW menjawab, "Ya, meskipun kamu (berwudhu) di sungai yang mengalir." (HR. Ahmad) $)^{34}$.

Pandangan Hidup Pancasila berpangkal pada keyakinan bahwa alam semesta dengan segala hal yang ada di dalamnya sebagai suatu keseluruhan yang terjalin secara harmonis diciptakan oleh Tuhan Yang Maha Esa. Juga manusia diciptakan oleh Tuhan Yang Maha Esa. Manusia berasal dari Tuhan dan tujuan akhir dari kehidupannya adalah untuk kembali kepada sumber asalnya. Karena itu, bertaqwa dan mengabdi Tuhan menjadi kewajiban manusia yang wajar, yang sudah dengan sendirinya harus begitu. Manusia diciptakan Tuhan dengan kodrat sebagai mahluk bermasyarakat. Artinya, kehadiran manusia di dunia dikodratkan dalam kebersamaan dengan sesamanya. Dalam kebersamaannya itu, tiap manusia memiliki kepribadian yang unik yang membedakan yang satu dari yang lain. Keseluruhan pribadi-pribadi dengan 
keunikannya masing-masing mewujudkan satu kesatuan, yakni kemanusiaan. Dalam masing-masing pribadi yang unik itu terdapat atau terjelma kemanusiaan. Karena itu, kehadiran manusia dalam kebersamaannya memperlihatkan kodrat adanya kesatuan atau kesamaan, yakni kemanusiaan dalam pribadi-pribadi yang unik, yang berbeda. Berbentuk kesatuan dalam perbedaan. Dalam dinamika proses-proses kemasyarakatan, Pancasila diwujudkan dalam berbagai bidang kehidupan, juga pada bidang kehidupan hukum ${ }^{35}$.

Hukum Adat yang tumbuh dari dan di dalam lingkungan-lingkungan masyarakat Adat Indonesia, juga merupakan penjelmaan Pancasila pada bidang hukum pada tahap perkembangan tertentu. Karena itu, Hukum Adat adalah bagian dari Hukum (Nasional) Indonesia ${ }^{36}$. Dalam konteks Pengelolaan Sumber Daya Air, hukum adat dalam bentuk kearifan tradisional merupakan salah satu faktor yang mendukung pengelolaan sumber daya alam terpadu. Salah satu syarat keberhasilan program konservasi air adalah penerimaan sosial, kearifan tradisional yang mendukung konservasi sumber daya air yang masih dipraktekkan oleh masyarakat harus didukung oleh pemerintah, dengan memberikan perlindungan terhadap praktek-praktek tersebut, lebih lanjut dukungan tersebut perlu ditingkatkan dalam pemberian insentif.

Beberapa kearifan tradisional dalam konservasi sumber daya air adalah sebagai berikut ${ }^{37}$ :

1. Ilengi adalah Kearifan lokal dalam bentuk agroforestry yang yang ditemukan di Provinsi Gorontalo. Kearifan lokal dalam bentuk kombinasi tanaman musiman dan tanaman tahunan (agroforestry) ini sangat relevan dengan kebijakan konservasi sumber daya air karena sistem tanam ini menciptakan stratifikasi tajuk tanaman bertingkat sehingga efektif dalam pengendalian laju erosi. Namun demikian, kepentingan politik dan ekonomi melalui kegiatan pertambangan, perkebunan, dan perluasan pertanian mulai menghambat perkembangan sistem Ilengi. Padahal keberlanjutan Ilengi ini penting terutama mempertimbangkan sebagian wilayah hulu DAS di provinsi Gorontalo memiliki karakteristik curah hujan tinggi, kemiringan lereng besar, dan stabilitas tanah sedang-rendah (tanah berbatu dengan humus tanah

\footnotetext{
${ }^{35}$ B. Arief Shidarta, Ibid, hlm. 19.

${ }^{36} \mathrm{Id}$.

${ }^{37}$ Chay Asdak, Ibid, hlm. 34-35.
} 
tipis). Sistem tutupan lahan ini sesuai dengan karakteristik biofisik setempat dan efektif untuk mencegah terjadinya erosi karena laju aliran limpasan permukaan terkendali, mencegah longsor, dan meningkatkan laju infiltrasi.

2. Sulawesi Tenggara memiliki beberapa kearifan tradisional. Mondau adalah bentuk kearifan lokal di Kabupaten Konawe. Bentuk kearifan lokal ini adalah pembukaan lahan/tanah adat di kawasan hutan untuk tanaman padi diganti dengan tanaman tahunan/buah. Relevansinya dengan program konservasi sumber daya air adalah penanaman tanaman tahunan (pohon, buah) sangat efektif dalam mengurangi besarnya run-off dan besarnya erosi. Kearifan lokal lainnya adalah Kaindea yang ditemukan di Kabupaten Wakatobi dan Kabupaten Buton Utara, yaitu upaya lokal perlindungan mata air (tidak boleh menebang pohon, tapi boleh mengambil hasil non-kayunya). Di Kabupaten Wakatobi juga ditemukan kesepakatan/kearifan lokal yang diberi nama Motika, yaitu hutan diperuntukkan terbatas untuk bangunan rumah dan tidak dijual secara komersial.

3. Di Yogyakarta, kearifan lokal ditemukan dalam bentuk Wono Deso (hutan desa), dan Telogo Deso (pembuatan embung/kolam retensi] Pembangunan hutan desa dan terutama Telogo Deso dapat menjadi alternatif untuk penyediaan air untuk pertanian dan perikanan/peternakan, utamanya pada musim kemarau.

4. Lubuk Larangan di Kabupaten Mandailing Natal, Sumatera Utara adalah kesepakatan antar masyarakat dan pemuka masyarakat untuk menjaga kelestarian dan kebersihan air sungai dengan cara pelarangan mengambil ikan di luar waktu yang telah ditentukan dan disepakati bersama. Ikan tersebut sengaja ditebar ke sungai untuk dimanfaatkan bagi pengembangan desa di Kabupaten Mandailing Natal. Pemanenan ikan secara kolektif diatur waktunya sesuai dengan aturan yang disepakati dalam Lubuk Larangan. Pelanggaran terhadap aturan yang disepakati dikenakan denda Rp 5 juta/kejadian pelanggaran untuk kas desa. Pada dasarnya, Lubuk Larangan adalah konsepsi penguasaan sumberdaya alam (sungai), dari yang semula dipahami sebagai sumberdaya yang bisa diakses secara bebas oleh siapapun (open access) menjadi sumberdaya yang dimiliki secara komunal (communally owned resources).

5. Kearifan ekologi Dayak Meratus di Kalimantan Selatan dalam bentuk pelarangan peladangan berpindah dan penebangan pohon di pegunungan, dapat ditemukan di desa Angkipih dan desa Peramasan Kabupaten Banjar, Kalimantan Selatan. Aturan 
lokal tersebut dilandasi pemahaman bahwa kerusakan/degradasi yang terjadi di gunung tersebut akan mengganggu sumber daya air.

\section{PENUTUP}

\section{Kesimpulan}

Sejarah tentang hukum alam merupakan sejarah umat manusia dalam usahanya untuk menemukan apa yang dinamakan keadilan yang mutlak. Untuk memahami bagaimana keadilan dapat dicapai, penting untuk mempelajari kehidupan manusia dan perjalanan hidup serta realisasinya. Terdapat 3 prinsip keadilan, yaitu keadilan berdasarkan hak, keadilan berdasarkan kemampuan/jasa dan keadilan berdasarkan kebutuhan. Keadilan lingkungan dapat dikategorikan keadilan berdasarkan hak. Manusia berhak mendapat lingkungan yang sehat dan layak. Manusia juga berhak memanfaatkan sumber daya yang ada di lingkungan, termasuk di dalamnya adalah sumber daya air untuk kebutuhan hidupnya. Prinsip Keadilan yang sangat menonjol dalam Hukum Lingkungan menunjukkan pengaruh dari Aliran Hukum Alam, dan menjadi dasar bagi pengelolaan lingkungan di Indonesia.

Pengelolaan Sumber Daya Air di Indonesia berlandaskan pada prinsip efisiensi, keadilan dan keberlanjutan. Prinsip-prinsip ini menunjukkan pengaruh aliran hukum alam. Posisi air yang secara kodrati adalah hak asasi manusia juga menguatkan pengaruh aliran hukum alam. Selain itu pengaturan tentang air juga dapat dilihat dalam ajaran-ajaran agama di Indonesia. Lebih lanjut pengaturan air juga ditemukan dalam berbagai kearifan tradisional yang ada di Indonesia. Hal ini menunjukkan bahwa hubungan manusia dengan air bersumber dari hukum Tuhan, sehingga pengaturannya juga harus mengikuti hubungan alamiah tersebut. Manakala pengaturan manusia melanggar prinsip-prinsip mendasar tersebut, maka terjadilah kekacauan dan ketidak seimbangan dalam hubungan antara manusia dengan alam.

\section{Saran}

Hukum Lingkungan dan Hukum Sumber Daya Alam merupakan bagian dari Ilmu Hukum yang saat ini berkembang pesat. Berbagai aliran dan teori hukum mempengaruhi perkembangan Ilmu Hukum Lingkungan dan Ilmu Hukum Sumber Daya Alam termasuk prinsip-prinsip di dalamnya. Aliran Hukum Alam hanyalah satu dari aliran yang mempengaruhi perkembangannya. Dalam hal pengelolaan lingkungan 
dan sumber daya alam, teori-teori hukum lain yang berasal dari aliran postitivisme hukum, sociological jurisprudence, mahzab sejarah dan pragmatical legal realisme juga turut menyumbang berbagai prinsip yang kemudian digunakan dalam praktek pengelolaan lingkungan dan sumber daya alam. Sehingga perlu juga mempelajari pengaruh aliran dan teori hukum di luar aliran Hukum Alam untuk memperkaya pemahaman Hukum Lingkungan dan Hukum Sumber Daya Alam.

\section{DAFTAR PUSTAKA}

\section{Buku}

Amiruddin A. Dajaan Imami. (2014). Hukum Penataan Ruang Kawasan Pesisir: Harmonisasi dalam Pembangunan Berkelanjutan. Bandung: Logoz Publishing.

Bruggink, JJ. H. alih bahasa B. Arief Shidarta. (2015). Refleksi tentang Hukum: PengertianPengertian Dasar dalam Teori Hukum. Cetakan ke IV. Bandung: Citra Aditya Bakti. Chand, Hari. (2005). Modern Jurisprudence. Malaysia: Internasional Law Book Services.

Hart, H.L.A. alih bahasa M. Khozim. (2010). Konsep Hukum. Cetakan Kedua, Bandung: Penerbit Nusa Media.

Ida Nurlinda. (2014). Membangun Pluralisme Hukum dalam Kerangka Unifukasi Hukum Agraria. Bandung: Logoz Publishing.

Jimly Asshiddiqie. (2010). Green Constitution, Nuansa Hijau Undang-Undang Dasar Negara Republik Indonesia Tahun 1945. Jakarta: Rajawali Pres.

Kelsen, Hans. (2012). Pengantar Teori Hukum. Cetakan ke-IV. Bandung: Penerbit Nusa Media.

Kruha. (2016). Kajian Hak Atas Air. Bandung: Indi Book Corner.

Lili Rasjidi dan Ira Thania Rasjidi. (2007). Dasar Dasar Filsafat dan Teori Hukum. Cetakan ke-10. Bandung: Citra Aditya Bakti.

(2016). Pengantar Filsafat Hukum. Bandung: Penerbit Mandar Maju.

M. Daud Silalahi. (2001). Hukum Lingkungan Dalam Sistem Penegakan Hukum Lingkungan Indonesia. Bandung: Alumni.

Otto Soemarwoto. (2004). Atur Diri Sendiri: Paradigma Baru Pengelolaan Lingkungan Hidup. Cetakan ketiga. Yogyakarta: Gadjah Mada University Press.

Takdir Rahmadi. (2011). Hukum Lingkungan di Indonesia. Jakarta: Rajagrafindo. 
Zaky Yamani. (2012). Kehausan di Ladang Air: Pencurian Air di Kota Bandung dan Hak Warga yang Terabaikan. Bandung: LSPP.

\section{Peraturan Perundang-Undangan}

Peraturan Presiden Republik Indonesia Nomor 33 Tahun 2011 Tentang Kebijakan Nasional Pengelolaan Sumber Daya Air.

\section{Jurnal}

Inge Dwisvimiar. (2011). 'Keadilan dalam Perspektif Filsafat Ilmu Hukum'. Jurnal Dinamika Hukum. Semarang: Universitas Jenderal Soedirman.

Suadamara Ananda. (2006). 'Hukum dan Moralitas'. Jurnal Hukum Pro Justitia, Volume 24 No 3. Bandung: UNPAR.

\section{Sumber Lain}

B. Arief Sidharta. 16-17 Juli 2012. 'Filsafat Hukum dalam Konteks Ideologi Negara Pancasila (Makalah dipresentasikan dalam Konferensi ke-2 Asosiasi Filsafat Hukum Indonesia)'. Semarang: Epistema, Huma dan FH-UKS.

Chay Asdak. 2015. Laporan Akhir Kebijakan Nasional Konservasi Sumber Daya Air Terpadu. Bandung: UNPAD.

Hayu S. Prabowo. 3 Maret 2015. Konservasi Air Dalam Perspektif Islam. http://muilplhsda.org/konservasi-air-dalam-perspektif-islam/. Diunduh pada 25 Mei 2017 Pkl. 12.30.

Maret Priyanta. 2017. 'Pengelolaan Hutan Berkelanjutan dalam Kerangka Pembaruan Sistem Hukum Lingkungan dan Penataan Ruang berbasis Perubahan Iklim' (Disertasi yang tidak dipublikasikan, Program Pendidikan Doktor Ilmu Hukum, Fakultas Hukum Universitas Padjadjaran).

Ande Ahmad Sanusi. 25 September 2015. 'Pengembangan Infrastruktur wilayah', (Paparan dalam Diskusi Terbatas Pembangunan Infrastruktur di Jawa Barat), Bandung: UNPAD.

Rizky R Sigit. 2015. Air Perlu Dilestarikan. Inilah lima fakta air dan kondisinya di Indonesia. http:/ / www.mongabay.co.id/2015/03/23/air-perlu-dilestarikan-inilah-limafakta-air-dan-kondisinya-di-indonesia/. Diunduh 25 Mei 2017 Pkl. 14.00. 